\title{
FISCAL POLICY, INEQUALITY AND THE ETHNIC DIVIDE IN GUATEMALA
}

Maynor Cabrera, Nora Lustig and Hilcías Morán

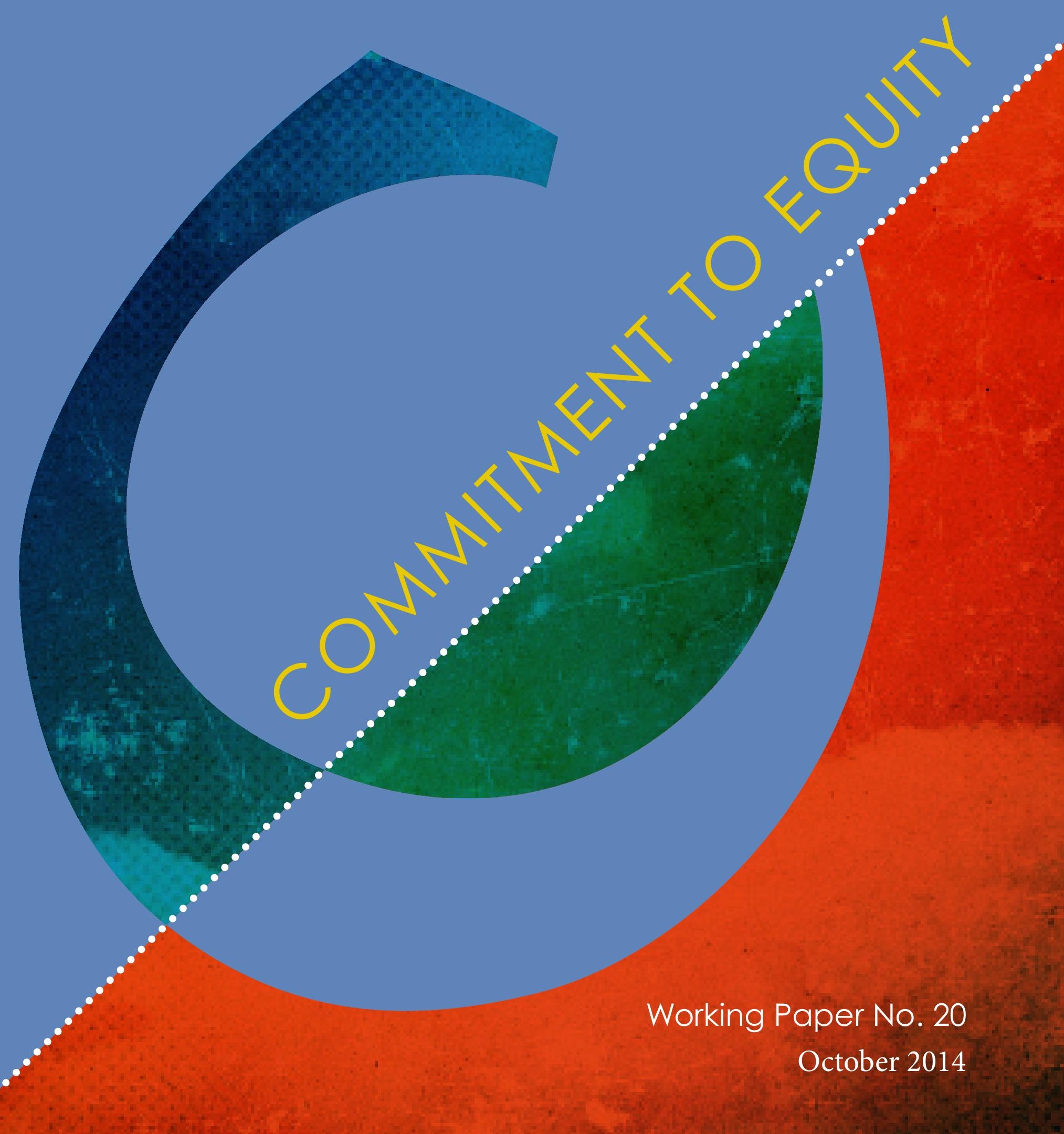




\section{FISCAL POLICY, INEQUALITY AND THE ETHNIC DIVIDE IN} GUATEMALA*

Maynor Cabrera (Fedes), Nora Lustig (Tulane University) and Hilcías E. Morán (Bank

of Guatemala)

CEQ Working Paper No. 20

OCTOBER 2014

\section{ABSTRACT}

Guatemala is one of the most unequal countries in Latin America and has the highest incidence of poverty. The indigenous population is more than twice as likely of being poor than the nonindigenous group. Fiscal incidence analysis based on the 2009-2010 National Survey of Family Income and Expenditures shows that taxes and transfers do almost nothing to reduce inequality and poverty overall or along ethnic and ruralurban lines. Persistently low tax revenues are the main limiting factor. Tax revenues are not only low but also regressive. Consumption taxes are regressive enough to offset the benefits of cash transfers: poverty after taxes and cash transfers is higher than market income poverty.

Keywords: inequality, poverty, ethnic divide, fiscal incidence, taxes, social spending, Guatemala

JEL Codes: D31, H22, I14

\footnotetext{
* An earlier version of this paper was presented at the conference "Commitment to Equity: Fiscal Policy and Income Redistribution in Latin America" held at Tulane University, October 17-18, 2013. The authors are grateful to conference participants for very useful comments. The study for Guatemala is part of the Commitment to Equity (CEQ) project. Led by Nora Lustig since 2008, the CEQ is a joint initiative of the Center for Inter-American Policy and the Department of Economics, Tulane University and the Inter-American Dialogue. The study for Guatemala has been partially funded by the Gender and Diversity Division of the Inter-American Development Bank.
} 


\section{INTRODUCTION}

Guatemala is among the most unequal countries and has one of the highest poverty rates in Latin America. ${ }^{1}$ The Gini coefficient for market income (i.e., before taxes and government transfers) equals 0.551 and the incidence of extreme poverty 35.9 percent. $^{2}$ With an incidence of poverty of 52.6 percent, an indigenous individual is more than twice as likely of being poor than a nonindigenous one. ${ }^{3}$ Although the indigenous population represents around 40 percent of the total population, 60 percent of the extreme poor are indigenous. ${ }^{4}$ Given the high incidence of poverty and inequality, and the sharp ethnic divide, how much redistribution, poverty reduction, and reduction of the welfare gap between the indigenous and nonindigenous population is accomplished through fiscal policy? We respond to this question by applying standard fiscal incidence analysis to examine the impact of taxes and social spending on income inequality and poverty for the entire population and by ethnic and rural-urban groups. We analyze the impact of fiscal policy on the income gap between the indigenous and nonindigenous population. We also examine how equitable the use of public health and education services is across income categories and between groups. The fiscal incidence method we apply is described in detail in Lustig and Higgins (2013). Known in the literature as the "accounting approach" (because ignores behavioral responses and general equilibrium effects), fiscal incidence analysis has a long tradition in applied public finance. ${ }^{5}$ For our incidence analysis, we use the 2009-2010 National Survey of Family Income and Expenditures (ENIGFAM).

Previous fiscal incidence studies for Guatemala or which include Guatemala in a multi-country study include Bahl et al. (1996), Barreix et al. (2009), Lindert et al. (2006) and Cubero and Hollar (2010). One common characteristic is that the data used by these studies were collected before the two main cash transfers programs were launched. The conditional cash transfer program (CCT) Mi Familia Progresa (MIFAPRO) started in 2008, and the noncontributory pension Economic Assistance Program for the Elderly (Programa de Aporte Económico del Adulto Mayor) began in 2006. In 2010, their combined budget was equal to 0.5 percent of GDP, small but not negligible. ${ }^{6}$ Per our results, these programs slightly increased the redistributive effect. Furthermore, to the best of our knowledge, ours is the first attempt to assess the impact of fiscal policy not only on income inequality and poverty, but also on inequalities between the indigenous and nonindigenous population.

The main contribution of our paper is twofold. We assess the effect of direct taxes, direct cash transfers, consumption taxes and subsidies, and public education and health spending on inequality, poverty and

\footnotetext{
${ }^{1}$ See reported indicators using disposable income in SEDLAC (Socioeconomic Database for Latin America and the Caribbean, CEDLAS at Universidad de La Plata and World Bank, 2013).

2 Both are measured with the 2009-2010 National Survey of Family Income and Expenditures (ENIGFAM), market income (i.e., before taxes and government transfers); poverty here is measured with the US $\$ 2.50$ ppp per day international poverty line. For more details, see sections 3 and 4, and Table 3.

3 The incidence of poverty for the nonindigenous group is equal to 24.5 percent.

4 According to the 2002 National Population Census, more than 40 percent of the population is indigenous, a figure that is practically the same as that obtained from the household survey used in this paper.

5 See, for example, the seminal work by Musgrave (1959) and Pechman (1985) as well as the more recent survey by MartinezVazquez (2008).

${ }^{6}$ For a description of social protection programs in Guatemala see, for example, Martinez (2013).
} 
coverage of public services in education and health not only for the population as a whole but also for indigenous-nonindigenous and rural-urban groups. Because we use a common methodology, we can compare the results for Guatemala with those of Bolivia, Brazil, and El Salvador. ${ }^{7}$ We have chosen these three countries as comparators because they either start from similar levels of market income inequality (Brazil) or the size of their economy measured in terms of per capita income ${ }^{8}$ is similar to Guatemala's (Bolivia and El Salvador). ${ }^{\text {? }}$

We find that the tax and transfer system does little to reduce inequality and the ethnic and rural-urban divide. The Gini coefficient after direct taxes and cash transfers declines from 0.551 to 0.546 , a mere 0.005 points. When the monetized value (at government cost) of education and health services are incorporated, the decline equals 0.024, still very small. Although direct taxes are somewhat progressive, they are painstakingly low. In contrast, consumption taxes are outright regressive and income inequality after direct and consumption taxes and direct transfers (which we call post-fiscal income) is the same as market income inequality. Even worse, consumption taxes are regressive enough that they more than offset the benefits to the poor of quite progressive cash transfers leaving post-fiscal poverty at a higher rate than market income poverty. The headcount ratio for market income equals 25.9 percent (with the US $\$ 2.50$ ppp international poverty line). With cash transfers (and direct taxes), it declines to 34.6 percent. However, consumption taxes bring the incidence of poverty to 36.5 percent.

The per capita income of the indigenous population -on average-is roughly one third of the nonindigenous one (32 percent on average). Taxes and transfers do almost nothing to change this dramatic difference in average living standards between the two groups. After all taxes and cash transfers, the ratio of per capita income between the indigenous and nonindigenous increases just from 32 to 33 percent. While the conditional cash transfers program Mi Familia Progresa is pro-poor and pro-indigenous, the size of the transfer is too small to make a significant difference, ${ }^{10}$ education spending is not pro-poor or pro-indigenous enough, and health spending reaches only a fraction of the poor. Inequality of opportunity (i.e., inequality due to circumstances) is not reduced at all. Compared with other countries, Guatemala has similar levels of inequality to Brazil but accomplishes a fraction of the latter's decline in inequality. When compared to Bolivia and El Salvador, two countries whose income per capita is similar to that of Guatemala, the tax and transfers system is more redistributive in the first two as well. ${ }^{11}$

\footnotetext{
${ }^{7}$ The common methodology can be found in Lustig and Higgins (2013), January version.

${ }^{8}$ Gross National Income in purchasing power parity, to be precise.

9 The study for Bolivia is from Paz-Arauco, et al. (2014); Brazil, from Higgins and Pereira (2014); and, El Salvador, Beneke et al. (2014).

${ }^{10}$ Since the year covered by this analysis (2010), the CCT program has suffered further cuts. According to data from the Ministry of Finance, the social spending on the CCT program Mi Familia Progresa reached its peak level in 2010 and it has gradually declined during the last four years. From 2010 to 2013 the expenditure in this program was reduced from 1,138.8 quetzales to 385 millions quetzales per year, respectively.

11 Our incidence analysis uses two scenarios. In the benchmark scenario, contributory pensions are treated as part of market income (assuming they are part of an actuarially fair system). A sensitivity analysis is done with contributory pensions included with the rest of government transfers and is available upon request. Qualitatively, the results with pensions as a transfer remain broadly the same.
} 
The paper is organized as follows. Section 2 briefly describes the tax and transfer system. The methodology and data are discussed in section 3. Section 4 presents the main results. Conclusions are in section 5.

\section{GOVERNMENT SPENDING AND TAXATION}

Tables 1 and 2 present public spending and tax revenues as a share of GDP for 2010--the year of the survey used in our incidence analysis--and identify which taxes and transfer programs were included in the incidence analysis (column "IA"). Measured by its budget, the size of Guatemala's government is very small. ${ }^{12}$ In 2010, total primary government spending (excluding interest payments) is only 13.6 percent of GDP, one of the lowest in Latin America. ${ }^{13}$ The tax burden (including social security contributions) in the same year is only 12.2 percent, again one of the lowest in Latin American and the Caribbean (See ICEFI, 2012). ${ }^{14}$

\section{i Social Spending and Subsidies}

At 5.5 percent of GDP, social spending is one of the lowest in the region as well. The cash transfers category includes a conditional cash transfers program, noncontributory pensions and a few other smaller ones. Altogether they represent 0.5 percent of GDP. ${ }^{15}$ In-kind transfers include social spending on education and health and are equal 5 percent of GDP). Non-social spending, contributory pensions and debt servicing represent $6.1,0.5$ and 1.5 of GDP, in that order. Contributory pensions (which are not included in social spending) equal 0.5 percent of GDP.

TABLE 1: GOVERNMENT SPENDING BY CATEGORY (2010)

\begin{tabular}{|l|c|}
\hline Government Spending (as a \% of GDP) & Guatemala (2010) \\
\hline Gross National Income per capita (PPP US\$) & Total IA $^{\text {a }}$ \\
\hline Total Government Spending $^{\mathrm{b}}$ & 4,630 \\
Primary Government Spending $^{\mathrm{c}}$ & $13.0 \%$ \\
\hline
\end{tabular}

\footnotetext{
12 The fiscal data used in this study corresponds to central government plus Social Security. Data on local governments includes transfers from Central Government to Municipalities (in 2010 close to 45 percent of total expenditure of local governments, according to Mininstry of Finance). Official Government Financial Statitics of Guatemala only covered Central Government.

13 For the share of primary spending in other countries in similar years, see Commitment to Equity/CEQ Standard Indicators (http://www.commitmentoequity.org/indicators.php). In countries like Brazil and Argentina which countries have the highest government expenditure, the primary government expenditure reaches more than 40 percent of GDP (see Lustig, et. al. 2013).

14 The difference between taxes and government expenditure is mostly financed with domestic and external debt. According to the data published by Ministry of Finance, fiscal deficit of Central Government in 2010 represented 3.3 percent of GDP.

15 Total cash transfers include other direct transfers, which are almost cero as a share of GDP.
} 


\begin{tabular}{|c|c|c|}
\hline Social Spending ${ }^{\mathrm{d}}$ & $5.5 \%$ & $5.5 \%$ \\
\hline Total Cash Transfers & $0.5 \%$ & $0.5 \%$ \\
\hline Cash Transfers (excluding all Pensions) & $0.4 \%$ & $0.4 \%$ \\
\hline Noncontributory Pensions & $0.1 \%$ & $0.1 \%$ \\
\hline Total In-kind Transfers & $5.0 \%$ & $5.0 \%$ \\
\hline Education & $2.6 \%$ & $2.6 \%$ \\
\hline of which Tertiary Education & $0.3 \%$ & $0.3 \%$ \\
\hline Health & $2.4 \%$ & $2.4 \%$ \\
\hline Contributory & $1.1 \%$ & $1.1 \%$ \\
\hline Noncontributory & $1.3 \%$ & $1.3 \%$ \\
\hline Other Social Spending ${ }^{\mathrm{e}}$ & $1.4 \%$ & $0.0 \%$ \\
\hline Non-Social Spending & $6.2 \%$ & $0.3 \%$ \\
\hline Indirect Subsidies & $0.3 \%$ & $0.3 \%$ \\
\hline Other Non-Social Spending & $5.9 \%$ & $0.0 \%$ \\
\hline Contributory Pensions & $0.5 \%$ & $0.5 \%$ \\
\hline Debt Servicing & $1.5 \%$ & $0.0 \%$ \\
\hline
\end{tabular}

Source: Ministerio de Finanzas Públicas, Superintendencia de Administración Tributaria SAT, Banco de Guatemala, Instituto Guatemalteco de Seguridad Social IGSS

a. In Incidence Analysis

b. Total Government Spending = Primary Government Spending + Debt Services (interests and amortizations)

c. Primary Government Spending $=$ Social Spending (w/o Contributory Pensions) + Non-social Spending (w/o Contributory Pensions) + Contributory Pensions

d. Social Spending $=$ Total Cash Transfers + Total In-kind Transfers.

e. Other social spending includes a considerable number of small social assistance programs that were not possible to identify from the data to be included in the incidence analysis.

\section{a Direct Transfers (Social Assistance)}

Spending on direct cash transfers (also called social assistance) comprehends five main programs (in 2010): a conditional cash transfer (CCT) called Mi Familia Progresa (MIFAPRO), a food transfer program called Bolsa Solidaria, a noncontributory pension program called Economic Assistance Program for the Elderly (Programa de Aporte Económico del Adulto Mayor), two educational scholarships program called Bolsa de estudio and Becas solidarias and a small cash transfer for transportation called Bono de Transporte. From this list, the most relevant programs are MIFAPRO and the noncontributory pension. Together they represent 0.5 percent of GDP; the rest are very small programs that altogether amount to 0.1 percent of GDP. 
Launched in 2008, the objective of MIFAPRO is to increase the human capital of younger generations in order to break the intergenerational cycle of poverty. The program provides two cash transfers, both targeted to poor women. First, a monthly health and nutrition cash transfer of 150 quetzals (local currency equivalent to 19 in current dollars of 2010, approximately) given to mothers of children under the age of six, to pregnant women and to breast-feeding mothers, under the condition that they attend health centers to receive a basic package of nutritional and preventive maternal-child health care services; and second, an education cash transfer of 150 quetzals given to poor families with at least one child between six and fifteen years old attending primary public school or preschool. Families can receive both transfers. Therefore, a family may get a cash transfer of up to 300 quetzals.

As observed in Table 1, in 2010 spending on Mifapro program is 0.4 percent of GDP. According to UNDP (2011), by January 2011, the beneficiary families equaled 862,000 and the population covered by the program was roughly equal to 4.8 million (or, about a third of Guatemala's total population of 14.4 million in 2010), of which 739,000 were children of age 0 to 5 years old and 1.6 million of age 6 to $15 .{ }^{16}$ As pointed out by Gaia (2010), however, the benefit is a fixed amount of cash not adjusted by the number of children, family size or any other special circumstance. Even though the coverage of this program is not that small (about a 32.9 percent of the poor receive benefits), the average transfer is very small. Taking into account the total amount of spending in this program in 2010, at 1,138 million quetzals (LCU), the average family benefit was roughly 110 quetzals per month. With an average household size of five, the per capita transfer is small: the equivalent of roughly 142010 dollars per person per month. What is more worrisome is that the program has become even smaller when a new government took office in 2012. The budget for Mifapro has been gradually reduced to only 0.1 percent of GDP in 2013.

The Economic Assistance Program for the Elderly (Programa de Aporte Económico del Adulto Mayor) was designed to provide a minimum living standard for the elderly poor population who are not beneficiaries of contributory pensions. In order to be eligible, people older than 65 years old have to apply to Ministry of Labor. If the socioeconomic status of one individual qualifies to become a beneficiary of the program, he or she obtains a monthly transfer of 400 quetzals (around USD 51). This program began in 2006 and by 2010 it had around 103,000 beneficiaries (18.6 percent of target population). In 2010 the social spending in this program represented 0.1 percent of GDP.

\section{b Subsidies}

The most important consumption subsidies are a subsidy on electricity for households who consume less than 300 Kilowatt hour per month and a public transportation subsidy that is delivered to owners of public buses (in Guatemala City and major cities of the country). Both subsidies represent 0.3 percent of GDP and

\footnotetext{
16 Since the target population for this program is larger than its financial capacity, at the beginning of the program the beneficiaries were chosen from municipalities according to a map of food vulnerability. It did not cover the entire country. Later they added other municipalities depending on the financial capacity of the government. At the end of 2008, the total amount of cash transfers handed out topped 116.7 millions of quetzals (around of US\$ 15 million, according to the Ministry of Finance) and benefited to 280,939 families (UNDP, 2011). There was a significant increase in coverage during 2009 and 2010 , by January 2011 the program covered 90 percent of municipalities and the budget of the program in 2011 reached almost 1 billion of quetzals (around of US\$125 millions).
} 
the beneficiaries live in urban areas. The public transportation subsidy is mostly given to individuals who use public transportation in Guatemala City.

\section{c Education system}

The educational system has three educational levels: preprimary (age 5 to 6 years), primary from $1^{\text {st }}$ to $6^{\text {th }}$ grade (age 7 to 12 years) and secondary, which include lower secondary school (basicos) from $7^{\text {th }}$ to $9^{\text {th }}$ grade (age 13 to 15 years) and high school (diversificado) from $10^{\text {th }}$ to $11 / 12^{\text {th }}$ (age 16 to $17 / 18$ years). The University of San Carlos of Guatemala (USAC), the sole public university, and 10 private universities provide higher education. The Technical Training and Productivity Institute (INTECAP in Spanish), a decentralized entity, provides technical training for current and prospective workers. In 2010, 53.2 percent of public expenditure on education went to primary education, 21.4 to secondary, 16.4 to tertiary education and 11 percent to pe-school.

\section{d Public health system}

The public health system comprises two main agencies: the noncontributory Ministry of Public Health and Social Assistance (Ministerio de Salud Pública y Asistencia Social, MSPAS) and the Health Program from IGSS. According to PAHO (2007), about 10 percent of the population had no access to any health services. Of those who had access to health services, 60 percent was covered by public services under MSPAS, 18 percent was served by IGSS and 12 percent used private services.

The IGSS provides health coverage to formal sector workers and their families, as well as pensions to retirees and individuals with permanent or transitory disability. Only 8 percent of the total population of Guatemala is affiliated to IGSS. The IGSS provides health services in only 11 of Guatemala's 22 departments, and its expenditures are disproportionately concentrated in the metropolitan area. While spending on noncontributory public health, as a percentage of GDP, (1.3 percent) is higher than contributory health spending (1.1 percent); however, in per capita terms the amount is much smaller given that-per PAHO's figures-- the Health Ministry provides healthcare services to a population that is more than three times larger than the population covered by the contributory system.

\section{e Social security system}

The social security system comprises the majority of social insurance programs in Guatemala, most of which are administered by the Guatemalan Institute of Social Security (IGSS). The social security system under the IGSS includes two programs: a health, maternity, and accidents insurance program called EMA (Enfermedad, Maternidad y Accidentes) and old age, disability, and alimony pensions program called IVS (Invalidez, Vejez y Sobrevivencia). As the social security system is based on contributions from formal employees and employers, the majority of its affiliates are formal workers. By 2011, approximately 25 percent of the economically active population was a member of the social security system.

The public sector pension system (IGSS) is organized on a pay-as-you-go basis. The contribution rates to the pension program (IVS) are 1.83 percent from employees and 3.67 percent from employers. The contributions to the health program (EMA) are 3 percent from employees and 7 percent from employers. 
Overall, public and private institutions must contribute to the system at the same contribution rates, but the government has not fulfilled all its liabilities for a long time. ${ }^{17}$

\section{ii Taxes}

In spite of the efforts made by successive governments to introduce revenue-raising tax reforms since the Peace Accords were signed in 1996, one of the structural features of the Guatemalan tax system is the low level of tax revenues. ${ }^{18}$ The tax structure for 2010, the year of the survey is shown in Table 2. Total tax revenue as a percentage of the GDP (including contributions to the social security system) is only 12.2 percent. Direct taxes comprised almost 27 percent of the total, while indirect taxes little over 60 percent. Of total direct taxes, personal income tax is only 2.9 percent. ${ }^{19}$ The VAT is over 40 percent of total tax revenues. The VAT general rate is 12 percent and zero for exports. Generic medicines, certain financial services, education, low value sales of food bought in cantonal and municipal markets (value less than 100 quetzales, approximately USD13) and resale of real estate property are exempt. Other indirect taxes, which include excise taxes on consumption of gasoline and diesel, beverages, tobacco, stamp tax, and cement, amount to 12.6 percent of total tax revenues.

TABLE 2: TAX REVENUES BY CATEGORY (2010)

\begin{tabular}{|l|r|r|r|}
\hline & \% Total & \% GDP & \multicolumn{1}{|c|}{$\mathbf{I A}^{\mathbf{a}}$} \\
\hline Total Tax Revenues & 100.0 & 12.2 & 7.7 \\
\hline Indirect taxes & 60.2 & 7.3 & 5.7 \\
\hline VAT & 41.8 & 5.1 & 5.1 \\
\hline Import taxes & 5.8 & 0.7 & - \\
\hline Other indirect taxes ${ }^{\mathrm{b}}$ & 12.6 & 1.5 & 0.6 \\
\hline Direct taxes & 26.9 & 3.3 & 0.4 \\
\hline
\end{tabular}

${ }^{17}$ Actually, the financial situation of the social security system is precarious because the government has not paid its dues for more than 10 years. According to press release published in the newspaper Siglo XXI on December 30 ${ }^{\text {th }}$ 2012, the debt accumulated by the government amounted Q21.6 billion by October 31 ${ }^{\text {st }} 2012$. This amount is equivalent to 6.5 percent of the 2012 GDP.

18 After a 36-year-long civil war, the Peace Accords established as a goal to increase the tax burden from 8 to 12 as a percentage of GDP from 1996 to 2000. Specifically, the Agreement on Social and Economic Aspects and Agrarian Situation identified several commitments to fiscal policy and it gave rise to the so-called Fiscal Pact in Guatemala. The unfortunate Fiscal Pact process had its formal beginning with the statement of rescheduling of compliance with the tax goal of the Peace Accords in October 1998 . It intended to raise taxes from 8 to 12 percent in 2002 and to take short-term actions in order to guarantee the gradual growth of the tax burden. However, this agreement has not been reached yet, even, after 15 years of signed.

${ }_{19}$ Import taxes (tariffs) have been reduced in recent years due to trade liberalization. According to WTO (2009), Guatemala's trade regime is essentially an open one. The average rate of MFN duty applied fell from 7.0 percent in 2001 to 5.9 percent in 2008. Guatemala has bound all its tariffs at an average rate of 42.7 percent. 


\begin{tabular}{|l|r|r|r|}
\hline Personal Income & 2.9 & 0.4 & 0.4 \\
\hline Corporate Income Tax & 22.4 & 2.7 & - \\
\hline Other Income Tax & 0.1 & 0.0 & - \\
\hline Property Tax & 1.6 & 0.2 & - \\
\hline Social Security Contributions & 12.9 & 1.6 & 1.6 \\
\hline
\end{tabular}

Source: Own calculations based on data of Ministry of Finance.

Notes: a categories included in the incidence analysis; b Includes Stamp Tax, Excises on Tobacco, beverages, cement, gasoline, diesel. Other indirect taxes not include in analysis were vehicles and royalties from extractive industries (mining and oil).

\section{METHODOLOGY, DATA AND ASSUMPTIONS}

\section{i Methodology}

We estimate the impact of taxes and transfers on inequality and poverty are calculated using fiscal incidence analysis. As described in Lustig and Higgins (2013), “... fiscal incidence analysis consists of allocating taxes and government spending to households so that one can compare incomes before taxes and transfers with incomes after taxes and transfers, where the latter may include the monetized value of free public services. The most common fiscal incidence analysis examines what is paid and received without assessing the behavioral responses that taxes and public spending may trigger. This is often referred to as the "accounting approach. Although not modeled, behavioral responses can be taken into account by imbedding them in the assumptions of who bear the burden of a tax or receive the benefit of a transfer. "Put simply, the accounting approach consists of starting from a pre-fisc income and, depending on the fiscal intervention under study, allocating the proper amount of a tax or a transfer to each household or individual. If the fiscal intervention is a direct tax (transfer) and one starts the analysis from pre-tax (pretransfer) income, the post-tax (post-transfer) income, the post-tax (post-transfer) income is calculated by subtracting (adding) the tax paid (transfer received).

More formally, let us define the before taxes and transfers income of unit $b$ as $I_{b}$, and net taxes of type $i$ as $T_{i}$. Let us define the "allocator" of tax $i$ to unit $h$ as $S_{i b}$ (or the share of net tax $i$ borne by unit $b$ ).

Then, post-tax income of unit $h$ can be defined as:

$$
Y_{b}=I_{b^{-}} \sum_{\mathrm{i}} T_{i} S_{i b}
$$

Although the theory is quite straightforward, its application can be fraught with complications. Most of the complications arise because actual incidence can be quite different from statutory incidence due to tax evasion or tax shifting and the data to calculate the actual incidence is incomplete or absent." (Lustig and Higgins, 2013) 
Following this approach, we constructed five income concepts that allow us to trace the incidence of the various taxes, transfers and subsidies: market, net market, disposable, post-fiscal, and final income (Diagram $1) .^{20}$

\section{Diagram 1}

\section{Fiscal Incidence Analysis: Income Concepts}

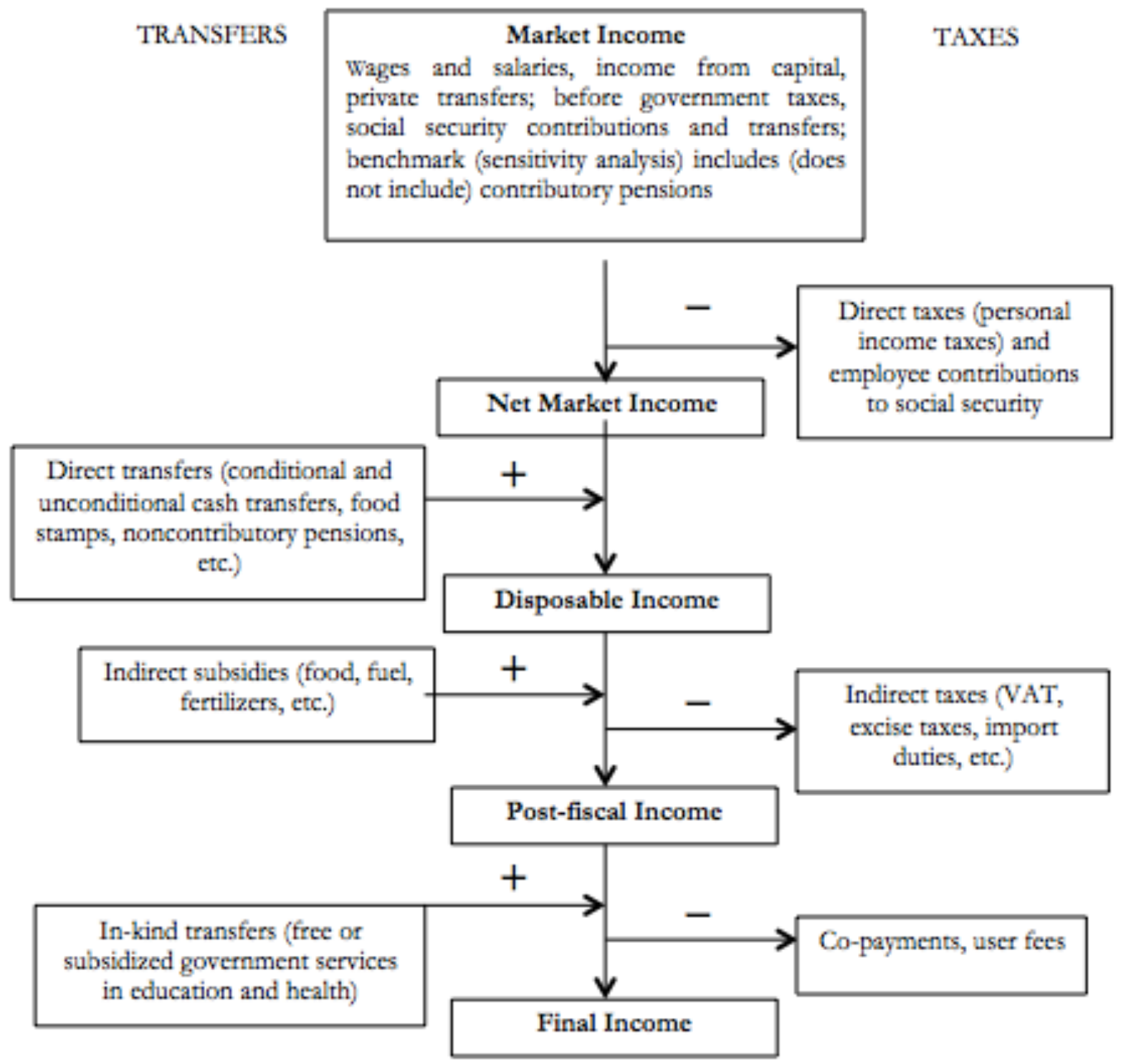

Source: Lustig and Higgins (2013).

${ }^{20}$ A detailed description of how each income concept was constructed for Guatemala-that is, which method was used to allocate each tax and spending category-is available upon request. 
Market income $e^{21}$ is total current income before direct taxes, ${ }^{22}$ equal to the sum of gross (pre-tax) wages and salaries in the formal and informal sectors (also known as earned income); income from capital (dividends, interest, profits, rents, etc.) in the formal and informal sectors (excludes capital gains and gifts); auto consumption; imputed rent for owner-occupied housing; private transfers (remittances and other private transfers such as alimony); and, in the benchmark scenario reported here, old-age and other pensions from the contributory social security system. ${ }^{23}$ Net market income equals market income minus direct personal income taxes on all income sources (included in market income) that are subject to taxation and all contributions to social security except for the portion going towards pensions. ${ }^{24}$ Disposable income is equal to the sum of net market income plus direct government transfers (mainly cash transfers but can include food transfers). Post-fiscal income is defined as disposable income plus indirect subsidies minus indirect taxes (e.g., value added tax, sales tax, etc.). Final income is defined as post-fiscal income plus the monetized value of government in-kind transfers in the form of free or subsidized services in primarily education and health minus co-payments or user fees. ${ }^{25}$ We also define final income* as disposable income plus government in-kind transfers in the form of free or subsidized services in education, health, and housing subsidies minus copayments or user fees (that is, this concept does not incorporate the effect of net indirect taxes). ${ }^{26}$

\section{ii Data}

The income concepts are constructed using the 2009-2010 National Survey of Family Income and Expenditures (in Spanish, Encuesta Nacional de Ingresos y Gastos Familiares -ENIGFAM-). Collected by the National Institute of Statics (INE) between 2009 and 2010, the sample covered 10,762 households and 53,432 individuals. The survey is representative at the national level, for rural and urban areas, and at the departmental level (the country is geographically divided in 22 departments). However, because the ENIGFAM does not have information on usage of health services, it was complemented with information in the National Survey on Living Conditions (Encuesta Nacional de Condiciones de Vida, ENCOVI) 2011. Data on government revenues and public spending come from the statistics published by the Ministry of Finance and IGSS. Aggregate data on the main macroeconomic variables come from the Central bank of Guatemala and data on education spending and enrollments comes from the Ministry of Education.

\footnotetext{
${ }^{21}$ Market income is sometimes also called primary income.

22 Taxes include all social security contributions except those for old-age pensions in the benchmark analysis and all social security contributions in the sensitivity analysis.

${ }^{23}$ In the fiscal incidence literature, pensions from contributory systems have been sometimes treated as part of market income and other times as government transfers. Arguments exist both for treating contributory pensions as part of market income because they are deferred income (see Lustig and Higgins, 2013, for references on both sides). Since this is an unresolved issue, in our study we defined a benchmark case in which contributory pensions are part of market income. We also performed a sensitivity analysis where pensions are classified under government transfers. The results presented here are for the benchmark analysis. The analysis with pensions as transfers is available upon request.

24 Since here we are treating contributory pensions as part of market income, the portion of the contributions to social security going towards pensions is treated as "saving."

25 One may also include participation costs such as transportation costs or foregone incomes because of use of time in obtaining benefits. In our study, they were not included.

26 The study excludes corporate and international trade taxes, some spending categories (such as infrastructure investments including urban services and rural roads that benefit the poor), and other public goods.
} 
For the incidence analysis by ethnic group, the population was classified into indigenous and nonindigenous groups based on self-reporting. ${ }^{27}$ By this definition, 40.7 percent of the surveyed population in Guatemala is classified as indigenous and 59.3 percent as nonindigenous. The incidence analysis by rural and urban areas used the definition of urban areas in ENIGFAM. Urban areas include the entire municipality of Guatemala, cities, villages and townships (capitals of departments and municipalities) with more than 2000 inhabitants as long as at least 51 percent of the household had access to electricity and piped water. The rest of the population is rural. Based on this definition, 52 percent of the population is classified as rural and 48 percent as urban.

\section{iii Assumptions}

\section{a Taxes}

Tax shifting assumptions are as follows. The burden of direct personal income taxes is borne entirely by the recipient of income. The burden of payroll and social security taxes (paid both by employee and employer) is assumed to fall entirely on workers. ${ }^{28}$ Consumption taxes are shifted forward to consumers. These assumptions are strong because, in essence, they imply that labor supply is perfectly inelastic and consumers have perfectly inelastic demands for goods and services. In the incidence literature, these assumptions are considered appropriate for first-round estimates and the short-run. ${ }^{29}$

In order to calculate Net Market Income we had to simulate PIT and contributions to social security. In the case of personal income tax (PIT), we computed it according to tax regime and informality assumptions. PIT has three regimes in 2010: (i) for wage earners there is a progressive schedule rates from 15 to 31 percent, and there may apply deductions and credit on VAT payments), (ii) net income regime, which is defined as gross income minus cost deductions and the tax rate is 31 percent) and (iii) gross income regime at rate of 5 percent. Regimes (ii) and (iii) include self-employed or employees who don't contribute to social security (that is, they work under "quasi-informal" conditions). ${ }^{30}$ Based on the information in the survey, we identify individuals who belong to each regime of personal income tax. We then simulate the taxes according to each regime's statutory rules but incorporating some assumptions regarding informality (tax evasion). In the case of wage earners we assume that employees and self-employed in firms with less than 10 workers do not pay PIT, unless they contributed to social security ${ }^{31}$. Also, we assumed that agricultural

\footnotetext{
27 The surveys ask the question: “To which indigenous group do you belong: 1. K'iche' 2. Q'eqchi' 3. Kaqchikel 4. Mam 5. Q'anjob'al...29. Nonindigenous 30. Foreigner.”

28 Since our incidence analysis starts with the reported labor market income before taxes and transfers, if employers transfer the burden of this contribution to the workers, this is captured implicitly as a lower market labor income received by employees. We do not include, however, an incidence analysis of the contributions paid by the employers and born by the employees in the form of lower wages.

${ }^{29}$ Some authors take a stronger view. For example, Martinez-Vazquez (2008, p. 123) argues that "...the results obtained with more realistic and laborious assumptions on elasticities tend to yield quite similar results."

${ }^{30}$ In some cases firms might belong to the formal sector, but some employees may be hired under gross personal income tax regime Hence, they are not covered by social security and other labor benefits received by regular employees.

31 It was necesary to make additional assumptions because in Guatemala some formal workers or independent high-skilled workers who fall under the flat income tax regime do not pay social security contributions. In our incidence analysis we do assume that these individuals pay personal income tax.
} 
workers hired on a daily basis (jornaleros) and those underemployed (individuals who reported working less than 40 hours per week) are assumed not to pay PIT either.

In the case of social security contributions, we identify the individuals who contribute to the social security system directly from the survey and estimate the value of their contribution by applying the statutory rate to their labor income. ${ }^{32}$ Estimates of employee contributions to social security were obtained by simulation based on reported income in the household survey and contributions established by Law.

In the case of the VAT, we calculated how much each household paid by multiplying consumption times the statutory rate. Of course, we assume that goods that are exempt by law do not pay this tax. ${ }^{33}$ We also assume that goods (more likely to be) sold in informal markets like unprocessed food (meat, vegetables, fruits, tortillas) in rural areas and in some small stores in urban areas (e.g., community markets, street vendors and local groceries) and some private services (i. e. gardening and house repair) do not pay VAT.

\section{$b$ Transfers}

The amount of direct transfers received by each household from Mi Familia Progresa, non-contributory pensions, transportation and scholarships programs are directly reported in the household survey.

In-kind education benefits are equal to the average spending per student by level (pre-school, primary, lower secondary, upper secondary and tertiary), which is obtained from financial statistics of the Ministry of Finance and administrative records of the Ministry of Education. ${ }^{34}$

To estimate in-kind health benefits, first we split the public health services into two categories: health services provided by social security facilities and health services provided by public health facilities. In the first case, we divide the total expenditure in health of the social security institute by the number of affiliates that were reported in the survey and then, we allocate this amount to each individual who lives in households that reported being part of the contributory health system. ${ }^{35}$ In the second case, we estimate the in-kind benefits of health expenditure of the Ministry of Health in outpatient services and hospital services by using as a secondary source the 2011 ENCOVI survey. To impute the results from the 2011 ENCOVI survey, we calculate the average benefit for 20 segments of income in each of the eight administrative regions of the country by residence (urban or rural) and ethnic group (indigenous/ nonindigenous). These values were imputed to equivalent population segments of ENIGFAM 2010. With this method, we have some household that are beneficiaries from health services provided by social security institute and some households that receive benefits from public health services.

\footnotetext{
32 Contributions by employees are 4.83 percent of wage income: 2.0 percent is for pensions and 2.83 percent for contributory health system.

33 The VAT rate is 12 percent, exempted goods of this tax are those goods bought in cantonal markets (value less than Q.100, LCU), generic medicines and education fees.

34 Spending on education includes administrative and capital expenditures.

35 The computation method for contributory health services may underestimate the size of benefit received by individual that use health services provided by social security system. This is because a fraction of individuals who contribute to social security system not necessarily use that health system. In some cases, when the individual has private health insurance, they would rather to use private health services. At this way, the effect on final income is a lower bound for those individuals that effectively use the contributive health services
} 


\section{MAIN RESULTS}

\section{a Income Inequality}

Table 3 reports the Gini coefficient and the headcount ratio for the (defined above) income concepts at the national level, urban and rural areas, and for the indigenous and nonindigenous population. ${ }^{36}$ At 0.551 , the market income Gini coefficient stands quite high and close to Brazil's 0.579. In contrast to Brazil, however, the effect of taxes and transfers on inequality is negligible even when the monetized value of education and health spending is taken into account: compare the Gini coefficient for final income and for market income in Table 4. While in Guatemala the reduction is a mere 0.024 Gini points, ${ }^{37}$ in Brazil all taxes and transfers combined reduce the Gini coefficient by 0.14 points. ${ }^{38}$

TABLE 3: FISCAL POLICY, INEQUALITY AND POVERTY IN GUATEMALA (2010)

(Gini Coefficient and Headcount Ratio)

\begin{tabular}{|c|c|c|c|c|c|c|}
\hline & Ethnicity & Market & Net Market & Disposable & Post-fiscal & Final \\
\hline \multirow{5}{*}{ Gini coefficient } & National & 0.551 & 0.550 & 0.546 & 0.551 & 0.527 \\
\hline & Rural & 0.515 & 0.515 & 0.508 & 0.515 & 0.484 \\
\hline & Urban & 0.531 & 0.530 & 0.528 & 0.533 & 0.514 \\
\hline & Non-Indigenous & 0.541 & 0.541 & 0.539 & 0.544 & 0.523 \\
\hline & Indigenous & 0.487 & 0.487 & 0.478 & 0.485 & 0.455 \\
\hline \multirow{5}{*}{ Poverty US\$2.5 PPP } & National & $35.9 \%$ & $36.2 \%$ & $34.6 \%$ & $36.5 \%$ & \\
\hline & Rural & $51.4 \%$ & $51.6 \%$ & $49.2 \%$ & $51.8 \%$ & \\
\hline & Urban & $19.2 \%$ & $19.5 \%$ & $18.8 \%$ & $19.8 \%$ & \\
\hline & Non-Indigenous & $24.5 \%$ & $24.7 \%$ & $24.0 \%$ & $25.5 \%$ & \\
\hline & Indigenous & $52.6 \%$ & $53.0 \%$ & $50.0 \%$ & $52.5 \%$ & \\
\hline \multirow{3}{*}{ Poverty US $\$ 4$ PPP } & National & $57.4 \%$ & $57.9 \%$ & $57.3 \%$ & $58.8 \%$ & \\
\hline & Rural & $76.3 \%$ & $76.6 \%$ & $75.7 \%$ & $77.1 \%$ & \\
\hline & Urban & $36.9 \%$ & $37.5 \%$ & $37.1 \%$ & $38.8 \%$ & \\
\hline
\end{tabular}

\footnotetext{
${ }^{36}$ Here we report the Gini coefficient and the headcount ratios. Other measures (such as the Theil index and quantile ratios; poverty gap and squared poverty gap ratios, and, poverty measures for different poverty lines) are available upon request.

${ }^{37}$ Barreix et al. (2009) found an even smaller reduction in the Gini: of 0.0053 points. One factor behind this difference is the fact that their study was done before the two main cash transfers were launched. Our study, in contrast, includes their effect.

${ }^{38}$ Higgins and Pereira (2014).
} 


\begin{tabular}{|c|c|c|c|c|c|}
\hline & Non-Indigenous & $43.5 \%$ & $44.2 \%$ & $43.8 \%$ & $45.5 \%$ \\
\hline & Indigenous & $77.6 \%$ & $77.8 \%$ & $76.8 \%$ & $78.1 \%$ \\
\hline \multirow{5}{*}{ National extreme PL } & National & $31.2 \%$ & $31.5 \%$ & $30.0 \%$ & $31.5 \%$ \\
\hline & Rural & $45.1 \%$ & $45.4 \%$ & $43.3 \%$ & $45.0 \%$ \\
\hline & Urban & $16.1 \%$ & $16.3 \%$ & $15.3 \%$ & $16.3 \%$ \\
\hline & Non-Indigenous & $20.6 \%$ & $20.9 \%$ & $20.3 \%$ & $21.6 \%$ \\
\hline & Indigenous & $46.6 \%$ & $47.0 \%$ & $44.2 \%$ & $46.0 \%$ \\
\hline \multirow{5}{*}{ National moderate PL } & National & $59.1 \%$ & $59.6 \%$ & $59.0 \%$ & $60.5 \%$ \\
\hline & Rural & $77.4 \%$ & $77.8 \%$ & $77.1 \%$ & $78.7 \%$ \\
\hline & Urban & $39.4 \%$ & $39.7 \%$ & $39.2 \%$ & $40.6 \%$ \\
\hline & \begin{tabular}{|l|} 
Non-Indigenous \\
\end{tabular} & $45.3 \%$ & $45.8 \%$ & $45.4 \%$ & $47.3 \%$ \\
\hline & Indigenous & $79.3 \%$ & $79.7 \%$ & $78.8 \%$ & $79.7 \%$ \\
\hline
\end{tabular}

Source: own calculations based on ENIGFAM 2010.

Note: For definitions see Diagram 1.

TABLE 4: FISCAL POLICY AND INEQUALITY: BOLIVIA, BRAZIL, COSTA RICA, EL SALVADOR AND GUATEMALA

(Gini coefficient)

\begin{tabular}{|l|c|c|c|c|c|c|c|}
\hline & $\begin{array}{c}\text { Market } \\
\text { Income }\end{array}$ & $\begin{array}{c}\text { Net } \\
\text { Market } \\
\text { Income }\end{array}$ & $\begin{array}{c}\text { Disposable } \\
\text { Income }\end{array}$ & $\begin{array}{c}\text { Post-Fiscal } \\
\text { Income }\end{array}$ & $\begin{array}{c}\text { Final } \\
\text { Income }\end{array}$ & $\begin{array}{c}\text { Disposable } \\
\text { vs. Market }\end{array}$ & $\begin{array}{c}\text { Final vs. } \\
\text { Market }\end{array}$ \\
\hline $\begin{array}{l}\text { Bolivia } \\
\mathbf{( 2 0 0 9 )}\end{array}$ & 0.503 & 0.503 & 0.493 & 0.503 & 0.446 & -0.010 & -0.057 \\
\hline $\begin{array}{l}\text { Brazil } \\
(\mathbf{2 0 0 9})\end{array}$ & 0.579 & 0.565 & 0.544 & 0.546 & 0.439 & -0.035 & -0.140 \\
\hline $\begin{array}{l}\text { Costa Rica } \\
\text { (2010) }\end{array}$ & 0.508 & 0.500 & 0.489 & 0.486 & 0.393 & -0.019 & -0.115 \\
\hline $\begin{array}{l}\text { E1 Salvador } \\
\text { (2011) }\end{array}$ & 0.440 & 0.436 & 0.430 & 0.429 & 0.404 & -0.010 & -0.036 \\
\hline $\begin{array}{l}\text { Guatemala } \\
\text { (2010) }\end{array}$ & 0.551 & 0.550 & 0.546 & 0.551 & 0.527 & -0.005 & -0.024 \\
\hline
\end{tabular}

Source: for Guatemala own calculations based on ENIGFAM 2010. Bolivia: Paz Arauco et al. (2014); Brazil: Higgins and Pereira (2014); Costa Rica: Sauma y Trejos (2014); El Salvador: Beneke et al. (2014). 
Compared with countries that have similar per capita income like Bolivia and El Salavador, Guatemala is less redistributive (Table 4). ${ }^{39}$ Although Guatemala spends more of its budget on social expenditures, both Bolivia and El Salvador have higher shares of primary government spending and, above all, social spending to GDP than Guatemala: social spending is 14.7 and 8.6 percent in the former compared to 6.9 percent of GDP in Guatemala. ${ }^{40}$ Redistribution is lower in Guatemala even though inequality is considerably higher than in both Bolivia (market income Gini equals 0.503) and, above all, El Salvador (0.44). If we leave out the contribution of education and health and focus on the effect on inequality of direct taxes and transfers, Guatemala comes out as the least redistributive as well. If we add the effect of net indirect taxes, redistribution becomes mil in both Bolivia and Guatemala while El Salvador still shows an equalizing effect (Table 4). Both Bolivia and Guatemala feature no decline in the post-fiscal income Gini vis-à-vis the market income Gini. That is, most of the difference between Bolivia and El Salvador vis-à-vis Guatemala is accounted after imputing the monetized value of government spending on education and health.

Although there is an attempt to target resources to the indigenous and the rural sectors, fiscal policy in Guatemala does little to equalize opportunities measured by the extent to which taxes and benefits reduce the inequality that can be attributed to circumstances beyond the individuals' control. Ideally, one would like to include characteristics of parents (e.g., education) among the pre-determined circumstances. In the case of Guatemala -and given data limitations - the 'circumstances' that could be used to measure inequality of opportunity are the head of household's gender, his or her ethnicity (indigenous vs. nonindigenous) and the current location of the household (rural vs. urban). Using the Mean Log Deviation as the inequality measure, in Table 5 one can observe that fiscal policy is not opportunity-equalizing because inequality of opportunity stays approximately constant across all income concepts. ${ }^{41}$ In contrast, in other countries (Brazil, for example), the fiscal system is opportunity-equalizing as inequality of opportunity falls from 0.0963 to 0.0496 as we move from market to final income (Higgins and Pereira, 2014).

\section{TABLE 5: INEQUALITY OF OPPORTUNITY (2009)}

\begin{tabular}{|l|r|}
\hline MLD of smoothed distribution & \\
\hline Income concept & Inequality of Opportunity \\
\hline Market & 0.198903 \\
\hline Net Market & 0.197078 \\
\hline Disposable & 0.196677 \\
\hline
\end{tabular}

\footnotetext{
${ }^{39}$ Data for Bolivia are from Paz-Arauco et al. (2014) and for El Salvador from Beneke et al. (2014). According to the World Bank World Development Indicators, GNI per capita was US\$3.919 ppp per year in Bolivia (2009) and US\$3,618 ppp in El Salvador (2011).

40 Social spending does not include spending on public contributory pensions.

41 The inequality of opportunity measure used here is based on the ideas first developed by Roemer (1998). For details see Barros et al. (2009). Each individual is attributed the mean income of their circumstances set, and this income distribution is called the smoothed income distribution. Inequality is then measured over the smoothed income distribution for each income concept using the mean $\log$ deviation, which gives the measure of inequality of opportunity in levels by income concept.
} 


\begin{tabular}{|l|r|} 
Post-fiscal & 0.189318 \\
\hline Final & 0.197449 \\
\hline
\end{tabular}

Source: own calculations based on ENIGFAM 2010.

Note: MLD means mean log deviation.

\section{b Poverty}

The incidence of poverty in Guatemala is also quite high, as shown in Table 3. Not surprisingly, the incidence of poverty is close to three times as high in rural areas and twice as high for the indigenous population. The indigenous population living with less than US $\$ 2.5$ ppp dollars per day (taken here as the international extreme poverty line for Latin America) is 52.6 percent, while the proportion of poor nonindigenous population is only 24.5 percent. The difference is even higher when we compare the rural and urban population: 51.4 percent versus 19.2 percent, respectively. ${ }^{42}$ Although the indigenous population represents around 40 percent of the total population, 60 percent of the extreme poor are indigenous. The rural population is 52 percent of the total population and 74 percent of the extreme poor.

The reduction in poverty induced by direct transfers (obtained by comparing net market with disposable income poverty rates) is quite small, the smallest when compared to Bolivia, Brazil, Costa Rica and El Salvador. Of countries with comparable data, the reduction is only smaller in Peru. ${ }^{43}$ Table 3 shows that the reduction is larger for rural than urban areas and for indigenous than nonindigenous population. This means that the resources are more targeted to the groups with the highest incidence of poverty, a desirable characteristic of anti-poverty policy. However, the reduction is still very small and hence the probability of being poor after cash transfers continues to be between twice and almost three times as high for the indigenous and rural population, respectively. Furthermore, when one takes into account the impact of indirect taxes, the poverty reducing effect of cash transfers is not only completely offset but post-fiscal income poverty is higher than market income poverty even in rural areas (where we assumed that people do not pay the VAT for food purchases).

\section{c Progressivity and Pro-poorness of Taxes and Transfers}

Table 6 shows the Kakwani progressivity index for taxes and transfers as well as the Reynolds-Smolenksy index for the fiscal system as a whole (except for in-kind transfers in education and health). ${ }^{44}$ Direct taxes are progressive and indirect taxes are quite regressive (the Kakwani index equals -0.12 ). Overall, the tax

\footnotetext{
42 The definition of urban and rural area in these surveys is based on the criteria of the 2002 National Population Census. Urban areas include cities, villages and towns (capitals of departments and municipalities) as well as places with the category of colonia or condominio and all places with more than 2000 habitants if in those places more than 51 percent of the households have electrical and piped water supply. Like in previous census, the whole territory of Guatemala City is considered as urban area. On the other hand, rural area is a residual area, defined as those places not included in the urban areas.

${ }^{43}$ For Argentina, Bolivia, Brazil, Mexico, Peru and Uruguay, see Lustig et al. (2014). For El Salvador, see Beneke et al. (2014).

44 The Kakwani index of tax progressivity is twice the area between the market income Lorenz curve and the tax concentration curve. If the tax concentration curve is above the Lorenz curve, the Kakwani index will be negative, which indicates that taxes are regressive in relative terms. The Reynolds-Smolensky of post-fiscal income with respect to market income is twice the area between the market income Lorenz curve and the concentration curve of post-fiscal income with respect to the market income distribution. Equivalently, the Reynolds-Smolensky can be calculated as the market income Gini minus the concentration coefficient of post-fiscal income when the population is ranked by market income.
} 
system is slightly regressive (-0.09). Direct transfers are progressive in absolute terms and so is the sum of direct and in-kind transfers. ${ }^{45}$ Because personal income taxes and direct transfers are very small, the vertical equity effect is negligible: the Reynolds-Smolenksy index of post-fiscal income with respect to market income is only 0.0006 .

\section{TABLE 6: MEASURES OF PROGRESSIVITY}

\begin{tabular}{|l|c|}
\hline Concept & Index \\
\hline Kakwani Index of Progressivity & \\
\hline Direct Transfers & -0.83 \\
\hline Direct and In-kind Transfers & -0.52 \\
\hline Direct Taxes & 0.30 \\
\hline Indirect Taxes & -0.12 \\
\hline All Taxes & -0.09 \\
\hline Reynolds-Smolensky Post Fiscal/Market Income & 0.0006 \\
\hline
\end{tabular}

Source: own calculations based on ENIGFAM 2010.

The unequalizing effect of indirect taxes is not their most problematic trait. After all, if regressive taxes are used to redistribute benefits to the poor, their regressive character may not be so reprehensible. However, as can be seen in Figure 1, indirect taxes are hurtful to the poor in terms of their purchasing power capacity because Guatemalan individuals with income between US1.25 and US $\$ 2.50$ become net payers to the fisc (in cash terms). Recall that in Table 3 we saw that extreme poverty measured by the US $\$ 2.50$ ppp a day line was higher for post-fiscal income than that for market income. That is, so many poor and near poor individuals are impoverished by, in particular, consumption taxes, that poverty ends up higher after fiscal interventions. This is the case in rural and urban areas and for nonindigenous population. For indigenous individuals the overall effect of taxes and direct transfers is almost nil.

One could argue that, still, even if in cash terms the poor are hurt, the regressive and poverty-increasing taxes are funding the access of the poor to education and health. True, as seen in Figure 3, final income shows that the poor are benefited — and benefited relatively more-- by the in-kind transfers in education and health. However, as we shall see in the next section, the usage of services is not universal, and many of the poor are still excluded.

\footnotetext{
45 Transfers are defined as progressive in absolute terms when the per capita benefit declines with income. Transfers that are progressive in absolute terms are called "pro-poor" (Davoodi et al., 2010). Transfers are defined as progressive in relative terms when the benefit as a proportion of market income declines with income (note that in this case the per capita benefit increases with income). When the per capita benefit is the same for everybody --a special case of a transfer that is progressive in relative terms-- it is often called "poverty neutral." Transfers are defined as regressive when the benefit as a proportion of market income increases with income. Progressive (regressive) transfers are equalizing (unequalizing).
} 
FIGURE 1 POST FISCAL AND FINAL INCOME

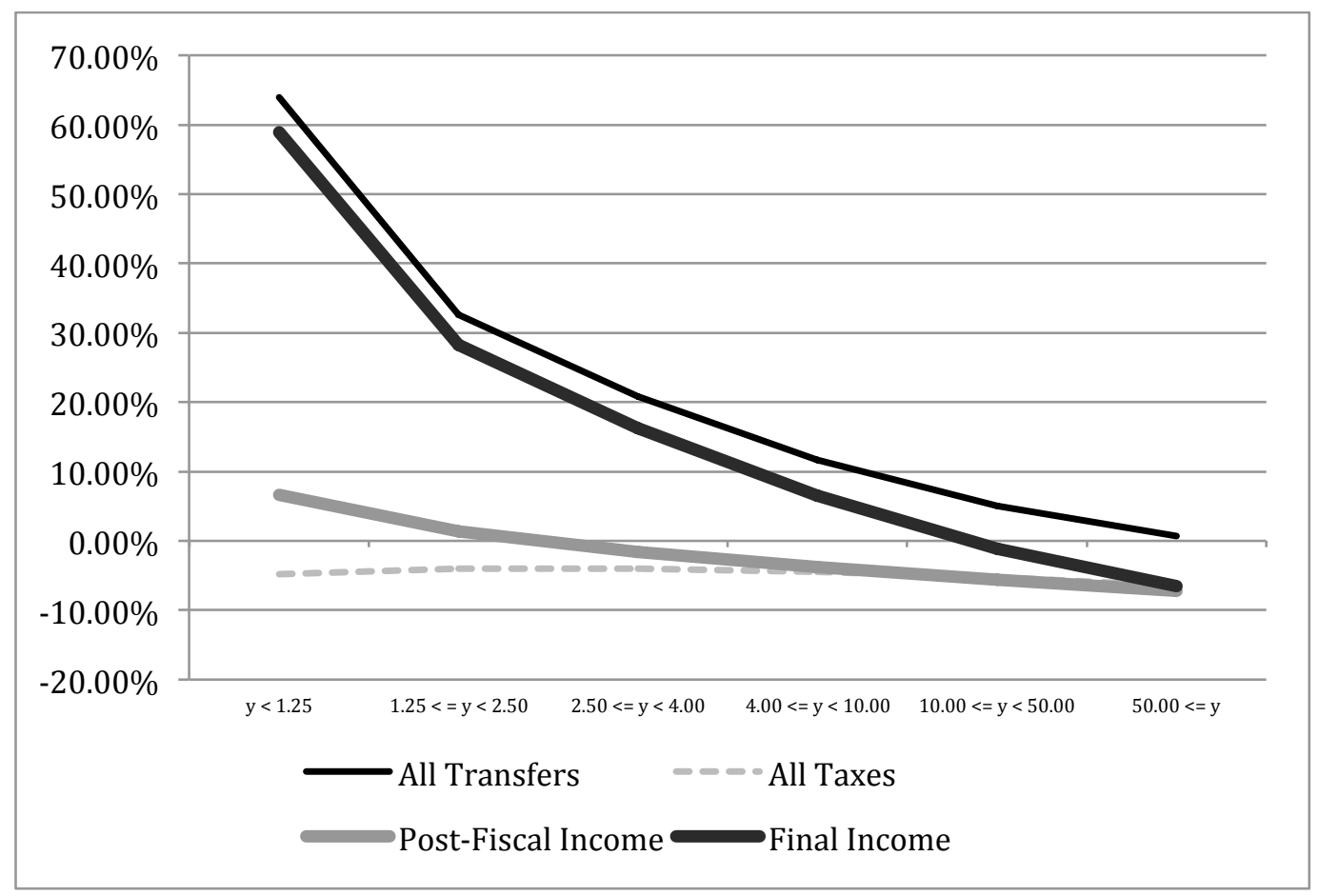

Source: own calculations based on ENIGFAM 2010.

The concentration coefficients in Figure 2 show that the CCT program Mi Familia Progresa, primary education and pre-school education are the most progressive and pro-poor spending categories. Lower secondary school, noncontributory pensions, and overall education spending are poverty neutral. The rest of the spending categories are progressive in relative terms in various degrees. Spending on tertiary education is outright regressive. The regressivity of tertiary education might be associated with low completion rates of primary and secondary education (Chamarbagwala \& Moran, 2011), which implies that a lower share of population may attend tertiary education. The budget allocated to tertiary education is higher than the budget allocated to upper secondary so this result is likely to persist as long as completion rates of primary and secondary education do not improve. 
FIGURE 2 CONCENTRATION COEFFICIENTS BY SPENDING CATEGORY

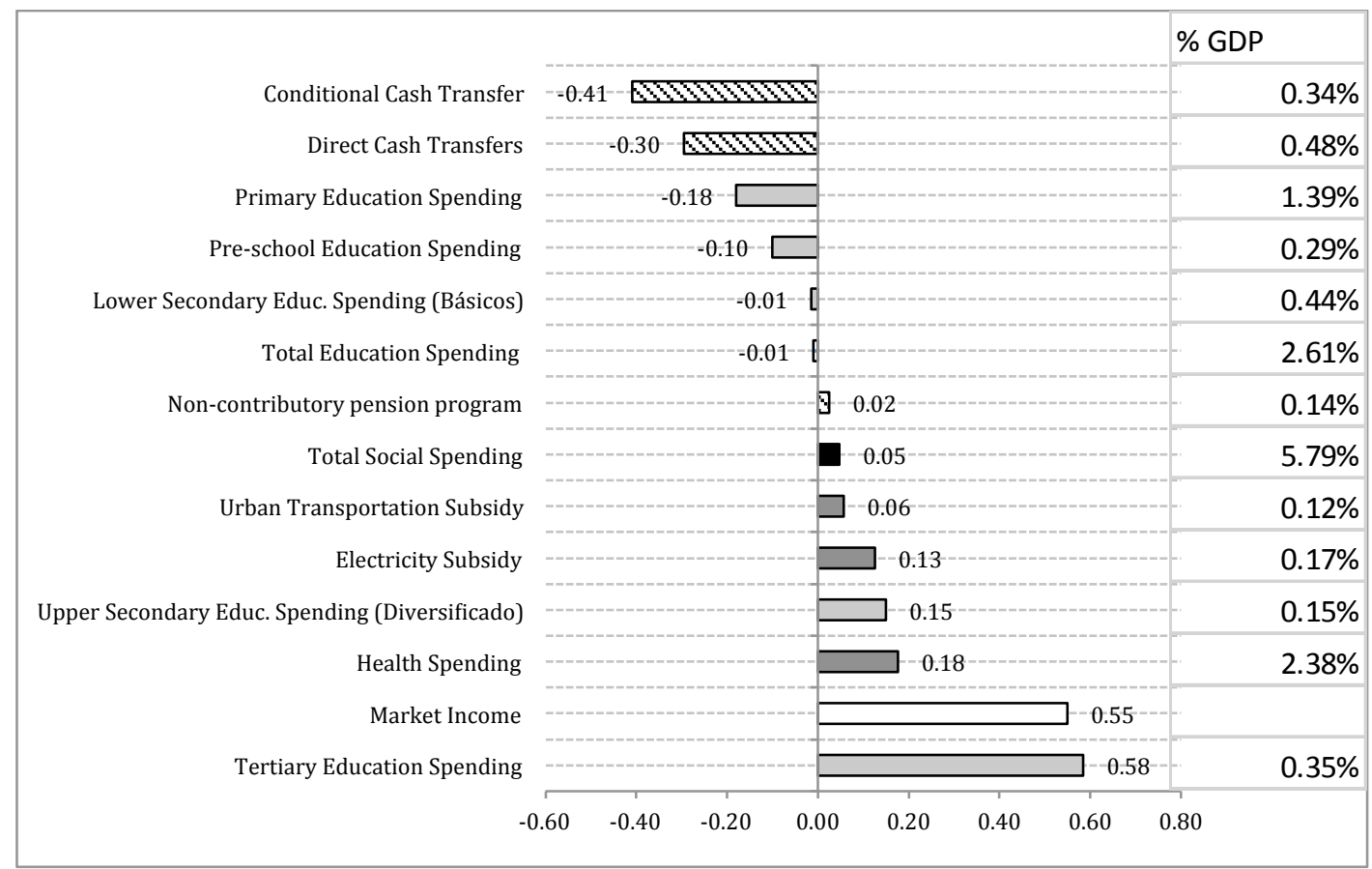

Source: own calculations based on ENIGFAM 2010. Note: The last column presents spending as a share of GDP. Definition of CEQ Social Spending: Sum of health spending, education spending, and social assistance spending. For this figure CEQ Social Spending does not include spending on contributory pensions from Social Security since contributory pensions are part of market income in the benchmark case, which is being used here.

\section{$d$ Taxes and Transfers and the Ethric Divide}

As we observed in Table 3, the probability of being poor (and extremely poor) is disproportionately higher for the indigenous population. In Table 7 we show another indicator of the ethnic divide: the distribution of income between the indigenous and nonindigenous population. The average market income per capita of the nonindigenous population is more than twice as high as that for the indigenous population. Taxes and transfers do almost nothing to change this dramatic difference in average living standards between the two ethnic groups. After all taxes and transfers are considered (including the monetized value of education and health), the ratio of per capita income between nonindigenous and indigenous individuals decreased from 2.13 to 2.03 .

To determine whether a tax is pro-indigenous, we ch eck whether the share of the tax is lower than the share of the indigenous population's market income in the total. By this measure, the tax burden of direct taxes falls largely on the nonindigenous population and the burden of indirect (consumption) taxes is proportional to their income. For public spending we use a more demanding measure to define an item as "pro-indigenous." We compare the share received by the indigenous group with their share in total population: the higher (lower) the former with respect to the latter, the more (less) pro-indigenous. In terms of direct transfers and subsidies, the only clearly pro-indigenous program is the CCT Mi Familia Progresa; its scale, however, is too small to make any significant inroads into the ethnic divide. Primary education spending is somewhat pro-indigenous and spending on pre-school and secondary are practically neutral: per 
capita benefits are roughly the same for each group. In contrast, tertiary education spending is highly prononindigenous and regressive in the ethno-space. Spending on health is outright not pro-indigenous.

TABLE 7: COMPARISON OF INCOME TAXES AND TRANSFERS BY ETHNIC GROUP (2010)

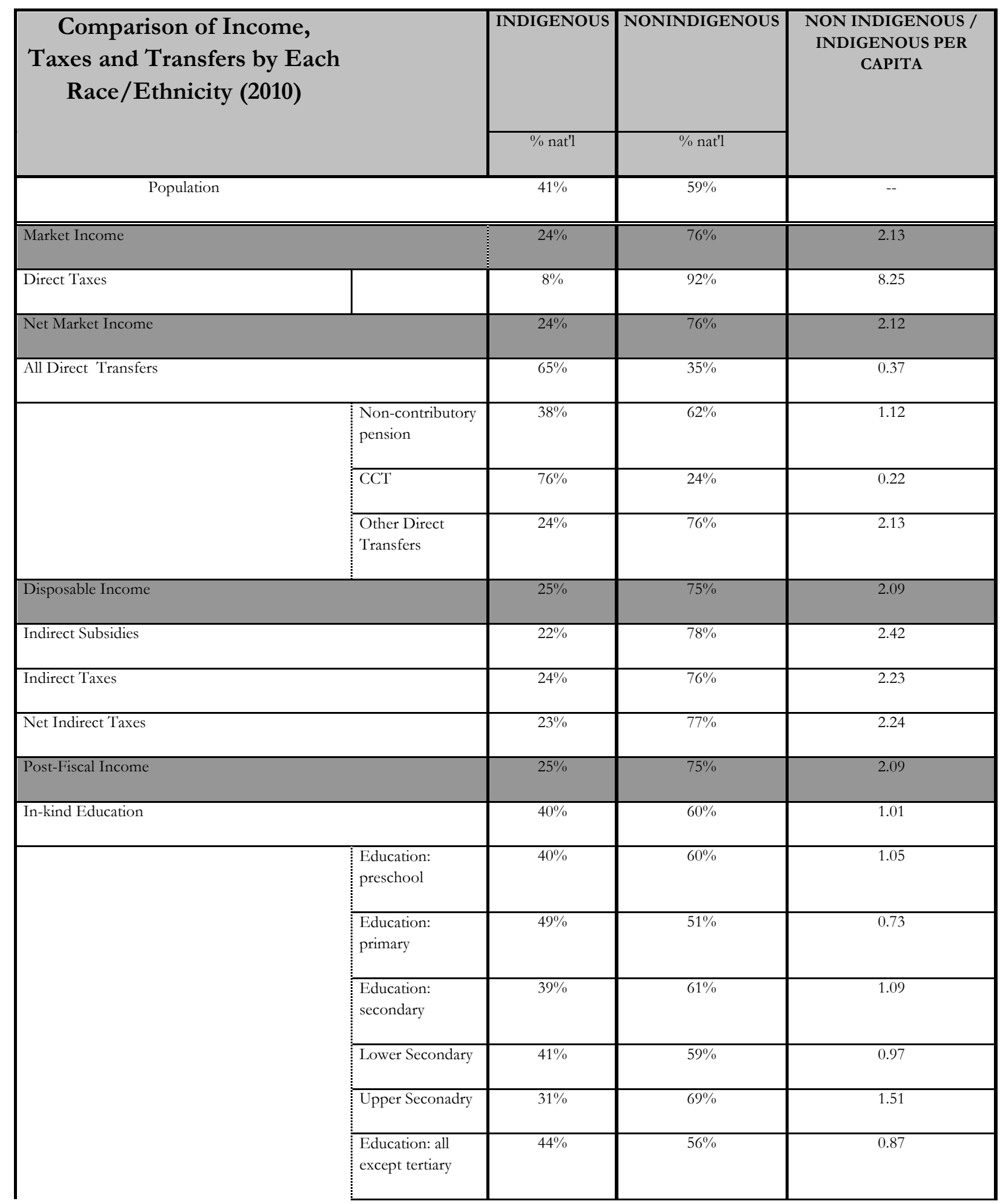




\begin{tabular}{|c|c|c|c|c|}
\hline & Education: tertiary & $14 \%$ & $86 \%$ & 4.25 \\
\hline In-kind Health & & $27 \%$ & $73 \%$ & 1.82 \\
\hline All Transfers & & $38 \%$ & $62 \%$ & 1.27 \\
\hline All Taxes & & $23 \%$ & $77 \%$ & 2.35 \\
\hline Final Income & & $25 \%$ & $75 \%$ & 2.03 \\
\hline
\end{tabular}

Source: own calculations based on ENIGFAM 2010. Note: it is important to mention that some of the items included in this table and in the incidence analysis of this study were scaled-up to make the totals match those from administrative accounts. The scaled-up items include: contributory pensions, electricity subsidy, transport subsidy, and VAT.

In cash terms (i.e., total taxes minus cash transfers and subsidies), both the indigenous and the nonindigenous population are net payers to the fiscal system. True, the nonindigenous share of the net payments to the fisc is 95 percent but, given the very high difference in average per capita incomes, one would have expected the nonindigenous population to subsidize the indigenous group to turn them - on average-into net beneficiaries (again, in cash terms) of the fiscal system. ${ }^{46}$ In other words, the redistribution of cash between the two groups is not sufficient to reduce the income gap (see Table 7). The net payments of both groups might be used to pay for public education and public health. With these inkind benefits, both groups become net beneficiaries of the fisc, which means that the funding for this comes from other sources of government revenue (corporate income taxes, import duties and other indirect taxes). Once the education and health benefits are taken into account, the average benefit is higher for the indigenous population than for the nonindigenous. That is, the indigenous get a share of benefits of in-kind transfers that is higher than the benefits received by the nonindigenous. Now, the question that arises is: are these in-kind transfers to the indigenous groups large "enough"? One way to answer this question is by looking at the coverage rates for education and health by income group for the indigenous and nonindigenous population to which we now turn.

In Table 8 we present the coverage of the CCT and education spending by income group and indigenous and nonindigenous groups. These coverage rates are calculated with the denominator being the target population: for example, for the CCT, the denominator is the total number of individuals living in households with children of the age that makes them eligible for the benefit. As one can observe, the CCT has a higher coverage for poor indigenous households than for equally poor nonindigenous ones. While this speaks to the pro-indigenous characteristic of this benefit, from a normative point of view one is left wondering why the transfer should not provide the same coverage to equally poor nonindigenous households. In terms of education, coverage for primary is similar for both groups but not for the other educational categories. In particular, the difference in coverage of secondary education for equally poor indigenous and nonindigenous groups probably reflects the higher drop-out rate among the indigenous. ${ }^{47}$

\footnotetext{
46 The numbers for these calculations are not shown here but are available upon request.

47 These numbers are consisten with the disparities in education attainment between nonindigenosu and indigenous. Accoriding to data from the 2002 National Population Census, the average years of schooling for nonindigenous and indigenos populations are 5.39 and 2.24, respectively. As showed by Chamarbagwala and Moran (2011), among individuals born between 1920 and 1983 , only $18 \%, 7 \%$ and $4 \%$ of indigenous individuals were able to complete primary, secondary and and high school, respectivly.
} 
One result to note is that the coverage of education among the nonindigenous falls with income for all categories except for tertiary (and for some categories among the indigenous). This may be a consequence of the middle-classes opting out of public education due to quality issues and returning to use the public option at the tertiary level. This phenomenon was observed in other countries in the region as well. ${ }^{48}$

\section{TABLE 8 COVERAGE BY INCOME GROUP: INDIGENOUS AND NONINDIGENOUS (2010)}

\begin{tabular}{|c|c|c|c|c|c|c|c|}
\hline INDIGENOUS & $\mathrm{y}<2.5$ & $2.5<y<4$ & $4<y<10$ & $10<y<50$ & $y>50$ & $y>4$ & Total \\
\hline CCT for individuals in households with children & $51 \%$ & $35 \%$ & $15 \%$ & $2 \%$ & $0 \%$ & $14 \%$ & $39 \%$ \\
\hline Education for pre-school aged children & $24 \%$ & $29 \%$ & $25 \%$ & $32 \%$ & & $25 \%$ & $25 \%$ \\
\hline Education for primary school aged children & $96 \%$ & $95 \%$ & $89 \%$ & $64 \%$ & na & $86 \%$ & $94 \%$ \\
\hline Education for secondary school aged children & $34 \%$ & $39 \%$ & $46 \%$ & $51 \%$ & & $46 \%$ & $38 \%$ \\
\hline Education for tertiary school aged children & $1 \%$ & $2 \%$ & $7 \%$ & $29 \%$ & & $9 \%$ & $3 \%$ \\
\hline Income shares & $26 \%$ & $24 \%$ & $34 \%$ & $15 \%$ & $1 \%$ & $50 \%$ & $100 \%$ \\
\hline Population shares & $53 \%$ & $25 \%$ & $19 \%$ & $3 \%$ & $0 \%$ & $22 \%$ & $100 \%$ \\
\hline NON INDIGENOUS & $y<2.5$ & $2.5<y<4$ & $4<y<10$ & $10<y<50$ & $y>50$ & $y>4$ & Total \\
\hline CCT for individuals in households with children & $23 \%$ & $8 \%$ & $2 \%$ & $1 \%$ & $0 \%$ & $2 \%$ & $9 \%$ \\
\hline Education for pre-school aged children & $33 \%$ & $35 \%$ & $31 \%$ & $16 \%$ & $5 \%$ & $28 \%$ & $31 \%$ \\
\hline Education for primary school aged children & $97 \%$ & $91 \%$ & $81 \%$ & $40 \%$ & $22 \%$ & $71 \%$ & $84 \%$ \\
\hline Education for secondary school aged children & $37 \%$ & $45 \%$ & $51 \%$ & $32 \%$ & $29 \%$ & $46 \%$ & $43 \%$ \\
\hline Education for tertiary school aged children & $1 \%$ & $4 \%$ & $11 \%$ & $34 \%$ & $12 \%$ & $17 \%$ & $11 \%$ \\
\hline Income shares & $6 \%$ & $9 \%$ & $35 \%$ & $43 \%$ & $7 \%$ & $85 \%$ & $100 \%$ \\
\hline Education for primary school aged children & $25 \%$ & $19 \%$ & $39 \%$ & $17 \%$ & $1 \%$ & $56 \%$ & $100 \%$ \\
\hline
\end{tabular}

Source: own calculations based on Enigfam 2010.

\section{CONCLUDING REMARKS}

This paper shows that fiscal policy does almost nothing to change the high levels of market income inequality and poverty and the stark ethnic welfare gaps in Guatemala. In the end, low direct tax revenues are, and will continue to be, the limiting factor for using fiscal policy as an effective tool to promote a more equalitarian society and providing a minimum standard of living and equalize opportunities. The

In contrast, the proportions of nonindigenos that completed primary, secondary and high school were $50 \%$, $29 \%$ and $19 \%$, respectively. In addition, when we compare urban an rural population the differences are even more significat (for a complete data on education attainment by gender, region, sector and ethnicity see Table 2 in Chamarbagwala and Moran (2011).

${ }^{48}$ See, for example, Lustig et al. (2014). 
Guatemalan fiscal system --in particular, its smallness and limited redistributive effect-- are the reflection of a polity that perpetuates deep inequities, in particular along ethnic and geographic lines. In their book on the 1990s Guatemalan tax reform, Bahl et al. state “... The government's objective in this tax reform program was more in the direction of investment enhancement and job creation than in establishing a large direct fiscal transfer of income to the poor. ... the net effect of the tax system changes were consistent with this objective." (Bahl et al., 1996, p. 142) Twenty years later, and judging by the results discussed in this paper, the objective seems to have remained unchanged. Guatemala is a textbook case of the power of elites to block pro-poor tax reforms (Corbacho et al., 2012, Box 2.1, pp 74-75). 


\section{REFERENCES}

Bahl, Roy W., Sally Wallace and Jorge Martinez-Vazquez (1996). The Guatemalan Tax Reform, Westview Press, Boulder, Colorado.

Barreix, A. M. Bes and J. Roca (2009), “Equidad Fiscal en Centroamérica, Panamá y República Dominicana,” BID-Eurosocial Fiscalidad, Washington, D.C.

Barros, Ricardo, F. H. G. Ferreira, Jose R. Molinas Vega, and Jaime Saavedra (2009), Measuring Inequality of Opportunities in Latin American and the Caribbean. International Bank for Reconstruction and Development/World Bank, Washington, DC.

Beneke, Margarita, Nora Lustig y José Andrés Oliva. 2014. El impacto de los impuestos y el gasto social en la desigualdad y la pobreza en El Salvador. CEQ Working Paper No. 26, Center for Inter-American Policy and Research and Department of Economics, Tulane University and Inter-American Dialogue. Forthcoming.

Cedlas and Worldbank (2013), Socio-Economic Database for Latin America and the Caribbean, viewed May 5, 2013, www.sedlac.depeco.unlp.edu.ar

Chamarbagwala, R., and Morán, H. (2011), “The Human Capital Consequences of Civil War: Evidence from Guatemala", Journal of Development Economics, 94, 41-61.

Corbacho, Ana, Vicente Fretes and Eduardo Lora. (2012). More Than Revenue: Taxation as a Development Tool. Inter-American Development Bank, Washington, DC.

Cubero, Rodrigo and Ivana Hollar (2010). "Equity and Fiscal Policy: The Income Distribution Effects of Taxation and Social Spending in Central America" IMF Working Paper 112, Washington, DC, May.

Davoodi, Hamid R., Erwin R. Tiongson and Sawitree Sachjapinan Asawanuchit. (2010). "Benefit Incidence of Public Education and Health Spending Worldwide: Evidence from a New Database.” Poverty \& Public Policy, Vol. 2: Iss. 2, Article 2.

Gaia, Elena (2010). "Mi Familia Progresa: Change and Continuity in Guatemala’s Social Policy, 22.

Higgins, Sean and Claudiney Pereira (2014). "The Effects of Brazil's Taxation and Social Spending on the Distribution of Household Income." In Lustig, Nora, Carola Pessino and John Scott. 2014. Editors. The Redistributive Impact of Taxes and Social Spending in Latin America. Special Issue. Public Finance Review, May, Volume 42, Issue 3

ICEFI (2007a). "Incidencia de los impuestos sobre la equidad en Guatemala”, Mimeo BID.

ICEFI (2007b). Incidencia del Gasto Público en Guatemala, Mimeo BID.

ICEFI (2012), "Second Central American Report on Fiscal Policy. Central American fiscal policy in times of crises", Executive summary, , viewed July 11 2012, http://www.icefi.org/admin/documents/563.

Lindert, Kathy, Emmanuel Skoufias and Joseph Shapiro (2006). "Redistributing Income to the Poor and the Rich: Public Transfers in Latin America and the Caribbean," Discussion Paper 0605. World Bank.

Lustig, Nora and Sean Higgins(2013). "Commitment to Equity Assessment (CEQ) A Diagnostic 
Framework to Assess Governments' Fiscal Policies Handbook.” MUST CITE WP , January.

Lustig, Nora, Carola Pessino and John Scott. Editors. (2014). The Redistributive Impact of Taxes and Social Spending in Latin America. Special Issue. Public Finance Review, May, Volume 42, Issue 3

Martinez F., Juliana (2013). "Social Protection Systems in Latin America and Caribbean, Guatemala", ECLAC, UN, Project Document LC/W.525.

Martinez-Vazquez, Jorge. (2008) "The Impact of Budgets on the Poor: Tax and Expenditure Benefit Incidence Analysis." in Moreno-Dodson, Blanca and Quentin Wodon. Eds. Public Finance for Poverty Reduction: Concepts and Case Studies from Africa and Latin America. Washington, DC: The World Bank.

Musgrave, Richard A. (1959). The Theory of Public Finance. New York: McGraw-Hill.

PAHO (2007), Health in the Americas 2007. Volume I: Regional, Scientific and Technical Publication No. 622. Washington (D. C.): Pan American Health Organization. Available: , http://www2.paho.org/saludenlasamericas/dmdocuments/health-americas-2007-vol-1.pdf Accessed 6 December 2013.

Paz Arauco, Verónica, George Gray Molina, Wilson Jiménez Pozo, and Ernesto Yáñez Aguilar. (2014). “Explaining Low Redistributive Impact in Bolivia." In Lustig, Nora, Carola Pessino and John Scott. 2014. Editors. The Redistributive Impact of Taxes and Social Spending in Latin America. Special Issue. Public Finance Review, May, Volume 42, Issue 3

Pechman, Joseph A. (1985). Who Paid the Taxes, 1966-1985. Washington, DC:Brookings Institution. Roemer, John (1998). Equality of Opportunity. Cambridge, MA: Harvard University Press.

Sahn, David and Stephen Younger. (2006). "Changes in Inequality and Poverty in Latin America: Looking Beyond Income to Health and Education." Journal Of Applied Economics. Vol. 9, Issue 2: 215-233, November.

UNDP (2011), "Ejercicio de Apreciación Sustantiva: Mi Familia Progresa (MIFAPRO)”, Guatemala.

World Bank (2009), “Guatemala Poverty Assessment”, Mimeo.

WTO (2009), “Trade Policy Review: Guatemala”, February 2009

(http://www.wto.org/english/tratop_e/tpr_e/tp310_e.htm) 


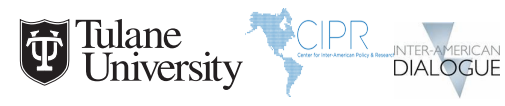

\section{CEQ WORKING PAPER SERIES}

\section{WORKING PAPER NO. 1}

Lustig, Nora and Sean Higgins. 2013. Commitment to Equity Assessment (CEQ): Estimating the Incidence of Social Spending, Subsidies and Taxes. Handbook. CEQ Working Paper No. 1, Center for Inter-American Policy and Research and Department of Economics, Tulane University and Inter-American Dialogue, September.

WORKING PAPER NO. 2

Lustig, Nora. 2013. Commitment to Equity: Diagnostic Questionnaire. CEQ Working Paper No. 2, Center for Inter-American Policy and Research and Department of Economics, Tulane University and InterAmerican Dialogue, January.

WORKING PAPER NO. 3

Lustig, Nora and George Gray Molina, Sean Higgins, Miguel Jaramillo, Wilson Jiménez, Veronica Paz, Claudiney Pereira, Carola Pessino, John Scott, and Ernesto Yañez. 2012. The Impact of Taxes and Social Spending on Inequality and Poverty in Argentina, Bolivia,Brazil, Mexico and Peru: A Synthesis of Results. CEQ Working Paper No. 3, Center for Inter-American Policy and Research and Department of Economics, Tulane University and Inter-American Dialogue, August.

WORKING PAPER NO. 4

Lustig, Nora and Sean Higgins. 2013. Fiscal Incidence, Fiscal Mobility and the Poor: A New Approach. CEQ Working Paper No. 4, Center for Inter-American Policy and Research and Department of Economics, Tulane University and Inter-American Dialogue, January.

WORKING PAPER NO. 5

Lustig, Nora and Carola Pessino. 2013. Social Spending and Income Redistribution in Argentina in the 2000s: the Rising Role of Noncontributory Pensions. CEQ Working Paper No. 5, Center for Inter-American Policy and Research and Department of Economics, Tulane University and Inter-American Dialogue, REVISED August 2013.

WORKING PAPER NO. 6

Paz Arauco, Verónica, George Gray Molina, Wilson Jiménez Pozo, and Ernesto Yáñez Aguilar. 2013. Explaining Low Redistributive Impact in Bolivia. CEQ Working Paper No. 6, Center for Inter-American Policy and Research and Department of Economics, Tulane University and Inter-American Dialogue, REVISED April.

WORKING PAPER NO. 7

Higgins, Sean and Claudiney Pereira. 2013. The Effects of Brazil's High Taxation and Social Spending on the Distribution of Household Income. CEQ Working Paper No. 7, Center for Inter-American Policy and Research and Department of Economics, Tulane University and Inter-American Dialogue, REVISED May 2013.

WORKING PAPER NO. 8

Scott, John. 2013. Redistributive Impact and Efficiency of Mexico's Fiscal System. CEQ Working Paper No. 8, Center for Inter-American Policy and Research and Department of Economics, Tulane University and 
Inter-American Dialogue, REVISED July 2013.

WORKING PAPER NO. 9

Jaramillo Baanante, Miguel. 2013. The Incidence of Social Spending and Taxes in Peru. CEQ Working Paper No. 9, Center for Inter-American Policy and Research and Department of Economics, Tulane University and Inter-American Dialogue, REVISED May 2013.

WORKING PAPER NO. 10

Bucheli, Marisa and Nora Lustig, Máximo Rossi and Florencia Amábile. 2013. Social Spending, Taxes, and Income Redistribution in Uruguay. CEQ Working Paper No. 10, Center for Inter-American Policy and Research and Department of Economics, Tulane University and Inter-American Dialogue, REVISED July 2013.

WORKING PAPER NO. 11

Higgins, Sean and Nora Lustig, Julio Ramirez and Billy Swanson. 2013. Social Spending, Taxes and Income Redistribution in Paraguay. CEQ Working Paper No. 11, Center for Inter-American Policy and Research and Department of Economics, Tulane University and Inter-American Dialogue, November.

WORKING PAPER NO. 12

Alvaredo, Facundo and Juliana Londoño Vélez. 2013. High Incomes and Personal Taxation in a Developing Economy: Colombia 1993-2010. CEQ Working Paper No. 12, Center for Inter-American Policy and Research and Department of Economics, Tulane University and Inter-American Dialogue, March.

WORKING PAPER NO. 13

Lustig, Nora, and Carola Pessino and John Scott. 2013. The Impact of Taxes and Social Spending on Inequality and Poverty in Argentina, Bolivia, Brazil, Mexico, Peru and Uruguay: An Overview. CEQ Working Paper No. 13, Center for Inter-American Policy and Research and Department of Economics, Tulane University and Inter-American Dialogue, REVISED August 2013.

WORKING PAPER NO. 14

Higgins, Sean and Nora Lustig. 2013. Measuring Impoverishment: An Overlooked Dimension of Fiscal Incidence. CEQ Working Paper No. 14, Center for Inter-American Policy and Research and Department of Economics, Tulane University and Inter-American Dialogue, April.

WORKING PAPER NO. 15

Tanzi, Vito. 2013. Tax Reform in Latin America: A long term assessment. CEQ Working Paper No. 15, Center for Inter-American Policy and Research and Department of Economics, Tulane University and InterAmerican Dialogue, April.

WORKING PAPER NO. 16

Higgins, Sean, Nora Lustig, Whitney Ruble and Tim Smeeding. 2013. Comparing the Incidence of Taxes and Social Spending in Brazil and the United States. CEQ Working Paper No. 16, Center for Inter-American Policy and Research and Department of Economics, Tulane University and Inter-American Dialogue, November.

WORKING PAPER NO. 17

López-Calva, Luis F., Nora Lustig, John Scott y Andrés Castañeda. 2014. Gasto social, redistribución del ingreso y reducción de la pobreza en México: evolución y comparación con Argentina, Brasil y Uruguay. CEQ Working Paper No. 17, Center for Inter-American Policy and Research and Department of Economics, Tulane University and Inter-American Dialogue, REVISED March.

WORKING PAPER NO. 18 Spanish

Sauma, Juan Diego Trejos. 2014. Gasto público social, impuestos, redistribución del ingreso y pobreza en Costa Rica. CEQ Working Paper No. 18, Center for Inter-American Policy and Research and Department of 
Economics, Tulane University and Inter-American Dialogue, January.

WORKING PAPER NO. 18 English

Sauma, Juan Diego Trejos. 2014. Social Public Spending, Taxes, Redistribution of Income, and Poverty in Costa. CEQ

Working Paper No. 18, Center for Inter-American Policy and Research and Department of Economics,

Tulane University and Inter-American Dialogue, January.

WORKING PAPER NO. 19

Amábile, Florencia, Marisa Bucheli and Máximo Rossi. 2014. Inequality and Poverty in Uruguay by Race: The

Impact of Fiscal Policies. CEQ Working Paper No. 19, Center for Inter-American Policy and Research and

Department of Economics, Tulane University and Inter-American Dialogue, February.

WORKING PAPER NO. 20

Cabrera, Maynor, Nora Lustig and Hilcías Morán. 2014. Fiscal Policy, Inequality and the Ethnic Divide in Guatemala. CEQ Working Paper No. 20, Center for Inter-American Policy and Research and Department of Economics, Tulane University and Inter-American Dialogue. Forthcoming.

WORKING PAPER NO. 21

Burdín, Gabriel, Fernando Esponda, and Andrea Vigorito. 2014. Inequality and top incomes in Uruguay: a comparison between household surveys and income tax micro-data. CEQ Working Paper No. 21, Center for InterAmerican Policy and Research and Department of Economics, Tulane University and Inter-American Dialogue, May.

WORKING PAPER NO. 22

Lustig, Nora. 2014. Fiscal policy and ethno-racial inequality in Bolivia, Brazil, Guatemala and Uruguay. CEQ Working Paper No. 22, Center for Inter-American Policy and Research and Department of Economics, Tulane University and Inter-American Dialogue. Forthcoming.

WORKING PAPER NO. 23

Lustig, Nora. 2014. Taxes, Transfers, Inequality and the Poor in the Developing World. Round 1. CEQ Working Paper No. 23, Center for Inter-American Policy and Research and Department of Economics, Tulane University and Inter-American Dialogue. Forthcoming.

WORKING PAPER NO. 24

Lustig, Nora and Marcela Melendez. 2014. The Impact of Taxes and Transfers on Inequality and Poverty in Colombia.

CEQ Working Paper No 24, Center for Inter-American Policy and Research and Department of

Economics, Tulane University and Inter-American Dialogue. Forthcoming.

WORKING PAPER NO. 25

Lustig Nora, Rodrigo Aranda and Ali Enami. 2014. Measuring the Contribution of Taxes and Transfers to Changes in Inequality and Poverty: How to Address Path Dependency. CEQ Working Paper No. 25, Center for InterAmerican Policy and Research and Department of Economics, Tulane University and InterAmerican Dialogue. Forthcoming.

WORKING PAPER NO. 26

Beneke, Margarita, Nora Lustig y José Andrés Oliva. 2014. El impacto de los impuestos y el gasto social en la desigualdad y la pobreza en El Salvador. CEQ Working Paper No. 26, Center for Inter-American Policy and Research and Department of Economics, Tulane University and Inter-American Dialogue. Forthcoming. 


\section{WHAT IS CEQ?}

Led by Nora Lustig since 2008, the Commitment to Equity (CEQ) project is an initiative of the Center for Inter-American Policy and the Department of Economics at Tulane University, the Center for Global Development and the Inter-American Dialogue. The project's main output is the CEQ Assessment, a methodological framework designed to analyze the impact of taxation and social spending on inequality and poverty in individual countries and to provide a roadmap for governments, multilateral institutions, and nongovernmental organizations in their efforts to build more equitable societies.

Since its inception, the CEQ has received financial support from Tulane University's Center for Inter-American Policy and Research, the School of Liberal Arts and the Stone Center for Latin American Studies as well as the Bill \& Melinda Gates Foundation, the Canadian International Development Agency (CIDA), the Development Bank of Latin America (CAF), the General Electric Foundation, the InterAmerican Development Bank (IADB), the International Fund for Agricultural Development (IFAD), the Norwegian Ministry of Foreign Affairs, OECD, the United Nations Development Programme's Regional Bureau for Latin America and the Caribbean (UNDP/ RBLAC), and the World Bank. www.commitmentoequity.org 